imposèrent au comité organisateur d'attendre que la liaison avec la colonie fût devenue plus normale. Après une série de prises de contact au cours des années i 945 et I 946 , il fut décidé que les travaux du prochain congrès seraient consacrés à l'étude de 'la question sociale indigène', et la date en fut fixée au 4 et $s$ octobre 1947 . Le congrès vient donc d'avoir lieu. A la séance inaugurale, M. le Ministre des Colonies annonça la dotation d'une somme de 2 milliards 350 millions au fonds du bien-être indigène. Ce fonds, qui permettra des dépenses annuelles d'un quart de milliard, aura pour mission d'aider matériellement, socialement et spirituellement les populations de l'intérieur; celles des centres extracoutumiers et des camps miniers étant confiées, sous la surveillance de l'État, à la responsabilité des employeurs.

Les rapports, présentés et discutés au congrès, furent l'œuvre de diverses commissions, présidées par des personnalités coloniales éminentes. Elles furent au nombre de dix, ayant respectivement comme objet: l'enseignement à tous les degrés pour indigènes, l'hygiène et la démographie, l'artisanat indigène, les cultures indigènes, les organisations sociales de chefferies, la main-d'œuvre indigène, l'organisation familiale, les évolués, le rôle social de la force publique. M. Max Horn, conseiller du gouvernement de la colonie, s'était chargé de coordonner les conclusions générales.

Nous ne pouvons songer à analyser chacun de ces rapports. Louons-en, dans l'ensemble, l'excellente venue, le sens de la réalité, le vif désir de progrès.

\title{
Institut pour la Recherche scientifique en Afrique centrale
}

PAR un arrêté en date du I juillet, x947, a été créé un institut pour la recherche scientifique en Afrique centrale, ayant pour l'objet de promouvoir, réaliser at coordonner, spécialement au Congo Belge et au Ruanda-Urundi, l'étude de l'homme et de la nature. A cette fin, il sera créé au Congo Belge et à Ruanda-Urundi un ou plusieurs centres où les chercheurs belges et étrangers pourront s'adonner à leurs études. L'Institut sera administré par un conseil composé de personnalités scientifiques belges et étrangers.

\section{Language Problems in Fundamental Education}

Nine experts (British, French, Belgian, American, Dutch, Czech) were summoned to Paris in July I 947 by U.N.E.S.C.O. to advise on the following questions : (I) How far are small tribal languages capable of serving the needs of modern education? (2) If the mother tongue must be used for the early teaching of children can a second language be taught at a later stage to break down the barriers of language difficulties? (3) How can the latest techniques of teaching languages with the aid of films and gramophone records be applied to fundamental education projects?

\section{Fundamental Education and the Use of the Cinema}

The British Film Institute organized a Conference on 'The Film in Colonial Development" on 16 January 1948. The Conference was opened by the Secretary of State for the Colonies and among the speakers was Mr. John Grierson, Director of Mass Communications in U.N.E.S.C.O. Mr. Grierson described the peoples of the world as being on the movementally and spiritually; as being in revolt against illiteracy and primitive conditions; this was a challenge to every citizen, especially to those of Great Britain (and other nations) who possessed the privilege and responsibility of governing colonial peoples. The present problem was itself the result of the world's riches and of the gap between technical invention and the knowledge of how to use it. He quoted the words of Julian Huxley: 'Man 
cannot exist partly literate and partly illiterate.' The task of fundamental education, however, was not merely to achieve literacy, but to enable men and women to live fuller lives, to develop their resources, and to take their places in the modern world; its aim was education for better living. It was important to be clear about the aims of fundamental education; the techniques would take care of themselves. Mr. Grierson referred to the pilot projects organized by U.N.E.S.C.O. in different areas with a view to gathering information, comparing results, and making the excellencies of each achievement available for the benefit of others. In pointing out that the citizens of the United Kingdom had a special interest in fundamental education, Mr. Grierson alluded to the work done by the Soviet Union in eliminating illiteracy and carrying out education in 200 vernacular languages, of which 90 were taught in schools. Referring to the Secretary of State's words in his opening address about the use of films in presenting European culture to African peoples, Mr. Grierson suggested that an equally important objective was the production of films in Africa by Africans and for Africans. The Cinema as an educational agency should not be considered in isolation; he would like to see in Britain a School of Colonies where a body of knowledge relating to all aspects of Colonial culture and development could be brought together. He would also like to see the development of the British Colonial Film Unit, with considerable decentralization and an extension of managerial and research functions to Africans; finally, he advocated a school of experimental cinema relating to Africa as a whole.

\section{East Africa Literature Committee}

FollowiNg the recommendations made by Mrs. Elspeth Huxley relating to the demand for literature among Africans in East Africa, the East African governments have agreed in principle to the establishment of an organization with headquarters in Nairobi to stimulate the production of books and other publications for the African populations of Kenya, Uganda, Tanganyika, and Zanzibar. In the first instance attention is to be concentrated on production in Swahili and Ganda, except in the case of school text-books; the question of providing literature in other East African languages and for Asians is to be considered later. Separate sections will deal with text-books, periodicals, general literature, distribution and business management, and libraries. The production of a popular magazine in English, Swahili, Ganda, Gang-Dholuo, and Kikuyu will be considered. It is proposed that the organization should stimulate the production of cheap books in Swahili and other East African languages on a variety of general subjects such as civics, biography, travel, local history, current events, \&c. It is also proposed that a central library system should be developed to which existing and proposed local libraries could be linked under the supervision of a trained librarian.

\section{Uganda African Literature Committee}

THis Committee was set up by the Chief Secretary, under the chairmanship of Mr. Snoxall, Deputy Director of Education. It is planned on a wide basis to be a channel for publishing approved works and to be a link between authors, publishers, and printers. It is prepared to advise writers on suitable books for translation, to criticize original books, and to explain the technicalities of publication. Its activities include the development of literacy and the establishment of a library service; in connexion with the latter, it has compiled and distributed instructions for librarians and a cataloguing system. The committee includes representatives of missions, government, commerce, and of Makerere College. 